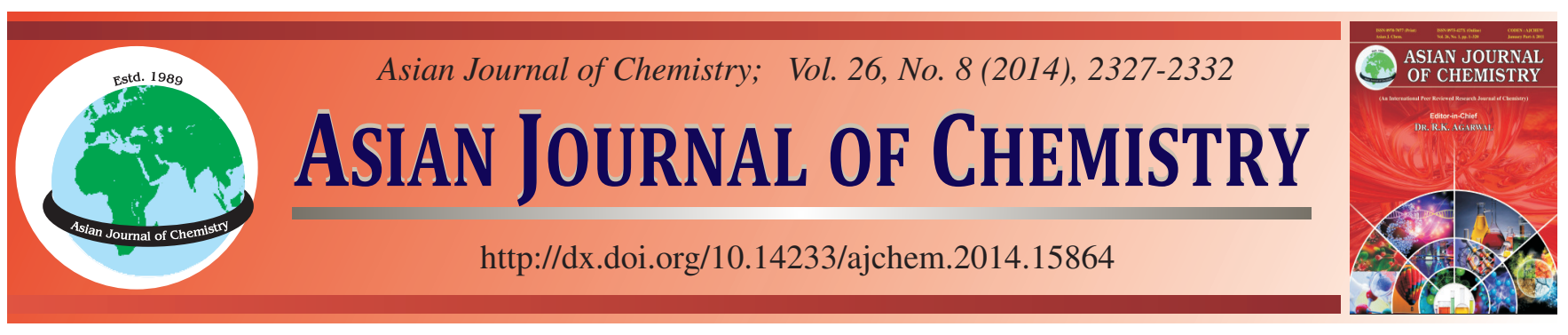

\title{
Influences of Pore Distribution of Carbon Electrodes on High-Rate Discharge Capacity and Cell Power in $\mathrm{Li} / \mathrm{SOCl}_{2}$ Cell
}

\author{
Jong Mok ChaE ${ }^{1}$, Kwang-Il Chung, ${ }^{2,}$, SAng Il LeE ${ }^{2}$ and Bum Soo KIm²
}

${ }^{1} 1$ st Team, Defense Agency for Technology and Quality-Daejeon Center, Daejeon, Republic of Korea

${ }^{2} \mathrm{R} \&$ D Center, Vitzrocell Co., Ltd., Chungnam Yesan, Republic of Korea

*Corresponding author: Fax: +82 41 3300190; Tel: +82 41 3300170; E-mail: kichung@ vitzrocell.com

\begin{abstract}
Discharge characteristics of $\mathrm{Li} / \mathrm{SOCl}_{2}$ cells are known to be affected by the pore size distributions of carbon electrode. In this study, we investigate effects of the pore distribution of the carbon cathode on the high-rate capacity and cell power. We carry SEM, mercury porosimetry and BET measurements for the characterization of carbon electrodes having different densities or various mixing ratio between acetylene black $(\mathrm{AB})$ and ketjen black $(\mathrm{KB})$. Upon the high-rate discharge characteristics, it is revealed that density effect is more significant than the effect of carbon mixing.
\end{abstract}

Keywords: Li battery, $\mathrm{Li} / \mathrm{SOCl}_{2}$ cell, High-rate capacity, Carbon pore.

\section{INTRODUCTION}

$\mathrm{Li} / \mathrm{SOCl}_{2}$ cell is an attractive primary battery due to its high specific energy, long shelf life and relatively long operating life ${ }^{1}$. The cell has long been employed as power sources requiring long operating life such as memory backup. However, there is a big demand on the improvement of the high-rate discharge capability of the cell because of the emergence of the devices requiring high power and long life at the same time, such as automatic meter reading systems, global positioning systems, tracking devices, RF-ID transponders and security devices.

$\mathrm{Li} / \mathrm{SOCl}_{2}$ cells consist of lithium ( $\mathrm{Li}$ ) anode, thionyl chloride $\left(\mathrm{SOCl}_{2}\right)$ liquid cathode and carbon electrode ${ }^{1}$. However, sometimes, carbon electrode is called as a cathode since it provides the site for the electrochemical reduction of $\mathrm{SOCl}_{2}$. Discharge reaction of the cell is following ${ }^{1}$;

Anode: $4 \mathrm{Li}(\mathrm{s}) \rightarrow 4 \mathrm{Li}^{+}+4 \mathrm{e}^{-}$

Cathode: $2 \mathrm{SOCl}_{2}(\mathrm{l})+4 \mathrm{Li}^{+}+4 \mathrm{e}^{-} \rightarrow 4 \mathrm{LiCl}(\mathrm{s})+\mathrm{SO}_{2}(\mathrm{~g})+\mathrm{S}(\mathrm{s})$ (Cathode: the porous carbon bonded by PTFE binder) Total: $4 \mathrm{Li}(\mathrm{s})+2 \mathrm{SOCl}_{2}(\mathrm{l}) \rightarrow 4 \mathrm{LiCl}(\mathrm{s})+\mathrm{SO}_{2}(\mathrm{~g})+\mathrm{S}(\mathrm{s})$

During the cell discharge, electrochemical reduction of $\mathrm{SOCl}_{2}$ takes place at porous carbon cathode and precipitate $\mathrm{LiCl}$ within pores of the carbon substrate as a reaction products $^{2}$. This leads to passivation film of $\mathrm{LiCl}$ on the carbon surface and resulting in cell failure. Especially, when discharge current is high, $\mathrm{LiCl}$ precipitation is formed near the mouth of the pores and then clogs the pores, although there are available reaction sites left inside of pores. This type of pore clogging is called as the carbon freeze-over which can be easily confirmed by monitoring carbon cathode surface of the discharged cell. From previous works ${ }^{3-7}$, it has been noticed that the cathode pore distribution plays significant role on the high-rate discharge capability of the $\mathrm{Li} / \mathrm{SOCl}_{2}$ cells. With the carbon electrodes having cathode freeze-over phenomena, $\mathrm{LiCl}$ precipitation at the mouth of pores known to interrupt $\mathrm{Li}^{+}$ion and $\mathrm{SOCl}_{2}$ to access inside pores of carbon electrodes. Therefore, it could be important to control the pore distribution of carbon cathode to improve high-rate discharge capability of $\mathrm{Li} / \mathrm{SOCl}_{2}$ cells.

Whereas, the electron conductivity of the cathode is a significant factor in order to improve the high power of the $\mathrm{Li} /$ $\mathrm{SOCl}_{2}$ cells. For this purpose the conductive carbon has been used as the additive of cathode materials. The conductive additive, reduces the pore amount of the cathode because it is filled into the pore to contact inter carbon particles.

In this work, we investigate how high discharge rate capability and cell power relate to the pore distribution of the cathode. To prepare carbon electrode having different pore distribution, we modify electrodes by either carbon density or mixing ratio of the conductive carbon. The test cells employed for the measurement of electrochemical characteristics are typical bobbin-type $\mathrm{D}$ size $\mathrm{Li} / \mathrm{SOCl}_{2}$ cell. The pore distribution of carbon electrodes are investigated by the mercury porosimetry, BET (Brunnauer, Emmett and Teller) and scanning 
electron microscopy (SEM). The high-rate discharge capability and cell power are confirmed by the discharge tester.

\section{EXPERIMENTAL}

Carbon cathodes with various mixing ratios were prepared from the mixtures of acetylene black (AB, Denka black $50 \%$ compressed) and ketjen black (KB, EC-300J) with a polytetra fluoro-ethylene (PTFE) binder. In mixtures, weight percentages (wt \%) of $\mathrm{KB}$ used as a conductive carbon to improve the conductivity of electrodes were 10, 20 and 50. To study density effect, we selected the electrode containing 10 weight percentages of $\mathrm{KB}$ and modified densities of the selected electrode were $0.25,0.27$ and 0.30 . Before assembling test cells, all of the cathodes were dried twice at $55^{\circ} \mathrm{C}$ for $2 \mathrm{~h}$ and then at $150{ }^{\circ} \mathrm{C}$ for $2 \mathrm{~h}$ in a forced convection oven. The test cells were assembled in the dry room controlling the relative humidity under $2 \%$.

General procedure: Configuration and size of the Li/ $\mathrm{SOCl}_{2}$ cell used in these experiments is bobbin-type D-size. Nominal capacity of the cell has known to be 19Ahr at the discharge rate of $4 \mathrm{~mA}$ at $25{ }^{\circ} \mathrm{C}^{8}$. Maximum current drain defined as the current drain providing $50 \%$ of the nominal capacity is $100 \mathrm{~mA}$. Electrochemical measurements were performed to evaluate the discharge capacity and working voltage of the test cells. The capacity and voltage variation were measured during constant current discharge at 100 or $250 \mathrm{~mA}$. All electrical measurements were carried by the Maccor 2400 discharger at room temperature.

Detection Method: FE-SEM (Field Emission-Scanning Electron Microscopy, JSM-7000F, JEOL) was employed to obtain SEM images of AB, KB and their mixture. Upon SEM measurements, working voltage and working distance of the lens were $15 \mathrm{kV}$ and $27 \mathrm{md}$, respectively. We also analyzed pore distribution of carbon samples by mercury porosimetry (AutoPore IV 9500, Micrometrics Instruments Corp.) method to support the results obtained from SEM studies.

We also employed BET (Brunnauer, Emmett and Teller, BELSORP-max, BEL Japan Inc.) as well as mercury porosimetric measurements to investigate the surface characteristic of carbon raw materials and the electrodes.

\section{RESULTS AND DISCUSSION}

Analysis of pore distribution of carbon materials: Fig. 1 shows SEM images of the carbon materials; AB [Fig. 1(a)], KB [Fig. 1(b) and mixture of AB:KB (9:1 weight ratio, Fig. 1(c)]. It is clearly seen that, in the sense of size and shape, pore distribution of $\mathrm{AB}$ is clearly different from that of $\mathrm{KB}$, although their primary particle size is similar. As shown in Fig. 1(a), AB particles are distributed roughly and provide relatively wider open structure of pores formed by an aggregate of spherical primary carbon particles. In case of $\mathrm{KB}$, pores formed between primary particles are smaller since $\mathrm{KB}$ particles seem to be more densely packed as shown in Fig. 1(b). From the SEM image of the mixtures shown in Fig. 1(c), it is noticed that open pore networks of $\mathrm{AB}$ are filled with $\mathrm{KB}$ particles. Therefore, decreases in pore volume of mixture comparing to that of $\mathrm{AB}$ only is expected.

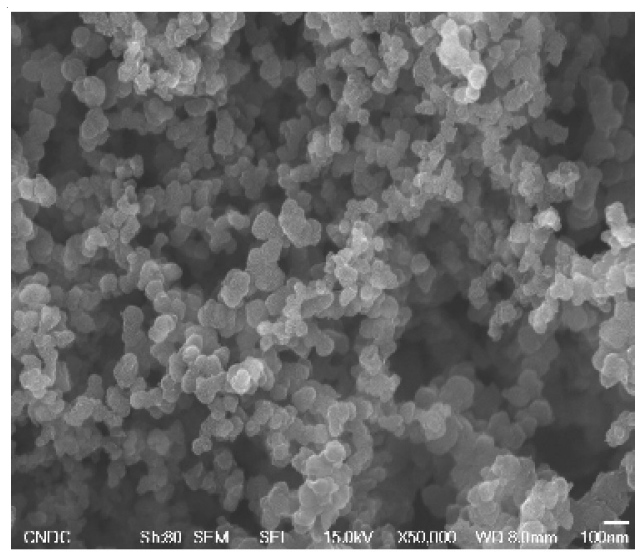

(a)

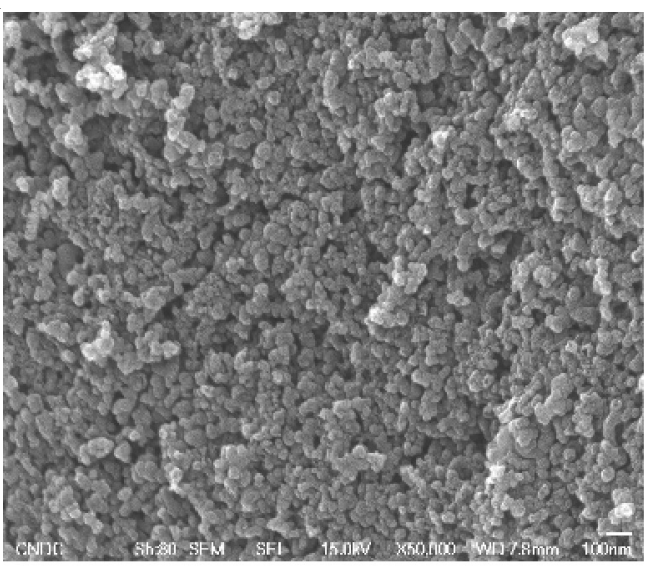

(b)

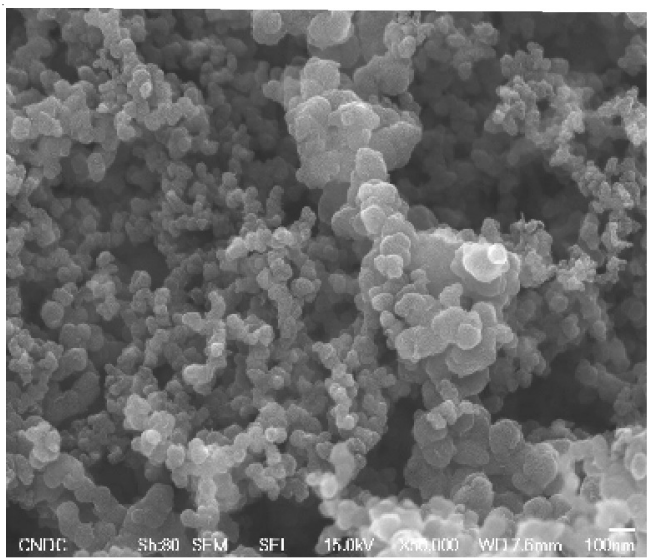

(c)

Fig. 1. Scanning electron micrographs of the carbons magnified at 50,000 times; (a) AB, (b) KB and (C) dry mixture of $\mathrm{AB}: \mathrm{KB}(9: 1 \mathrm{wt} \%)$

Fig. 2 shows the pore distribution of carbon materials obtained from mercury porosimeter. Although analysis of the distribution of micro sized pores $(<2 \mathrm{~nm})$ by mercury porosimetric method is not possible. It is clearly noticed from the figure that the pore size of $\mathrm{AB}$ is mainly in macro-pore region $(>50 \mathrm{~nm}$ ) while the size of $\mathrm{KB}$ is mainly in meso-pore region $(2-50 \mathrm{~nm})$. Comparing to $\mathrm{AB}$ only, decreases in pore size are also noticed from the mixture containing $10 \mathrm{wt} \%$ of $\mathrm{KB}$. A possible reason for the decrease in pore size is that wide open network pores formed by an $\mathrm{AB}$ aggregate are 


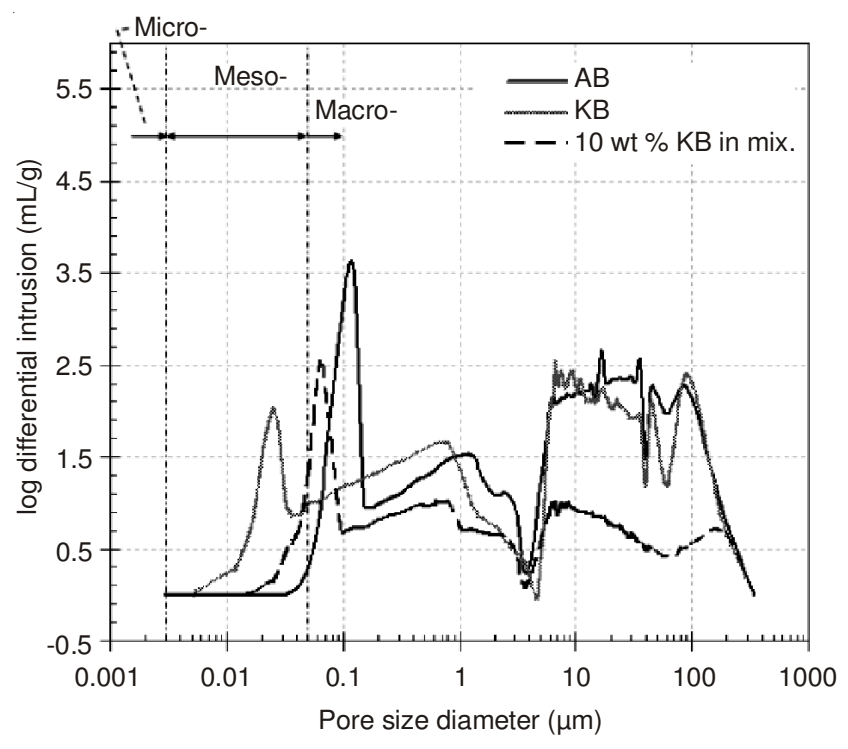

Fig. 2. Mercury porosimetric studies on the pore distribution of carbons: $\mathrm{AB}, \mathrm{KB}$ and mixture containing 10 wt $\%$ of $\mathrm{KB}$

partially filled with KB particles as shown in SEM image of mixture in Fig. 1(c).

Further characterization of carbon materials is carried by BET to complement mercury porosimetric measurements. Fig. 3 shows $\mathrm{N}_{2}$ adsorption isotherms of carbon materials; $\mathrm{AB}$, $\mathrm{KB}$ and mixture of 10 weight percentages of $\mathrm{KB}$ added. Based on the classification of types of adsorption isotherm, $\mathrm{KB}$ gives "Type VI" isotherm while AB and mixture of AB and KB show "Type III" isotherm. From the adsorption isotherm of KB, hysteresis loop which is a characteristic feature of a "Type IV" isotherm is noticed at the region where relative pressure $\left(\mathrm{P} / \mathrm{P}_{0}\right)$ is higher than 0.4 . From the hysteresis loop, it is also noticed that the quantity of adsorbed is greater along the desorption path than along the adsorption path. Hysteresis loop indicates that $\mathrm{KB}$ has meso-pore structure and the shape of pores could be ink-bottle type which has cylindrical pore closed one end and a narrow neck at the other end. Due to the capillary condensation in ink-bottle shape of measo-pores in $\mathrm{KB}$, hysteresis loop is observed. In the isotherm of $\mathrm{KB}$, existence of various sizes of meso-pores can be also postulated from the continuous increase in slope at the meso-pore region where the relative pressure $\left(\mathrm{P} / \mathrm{P}_{0}\right)$ is in between 0.1 and 0.95 . On the other hand, from sharp increases in slope at micro-pore region where the relative pressure $\left(\mathrm{P} / \mathrm{P}_{0}\right)$ is less than 0.1 in the adsorption isotherm of $\mathrm{KB}$, it is realized that $\mathrm{KB}$ has a number of micro-pores. Sharp increase in slope indicates that the interaction of $\mathrm{KB}$ with $\mathrm{N}_{2}$ gas may be strong enough even at a

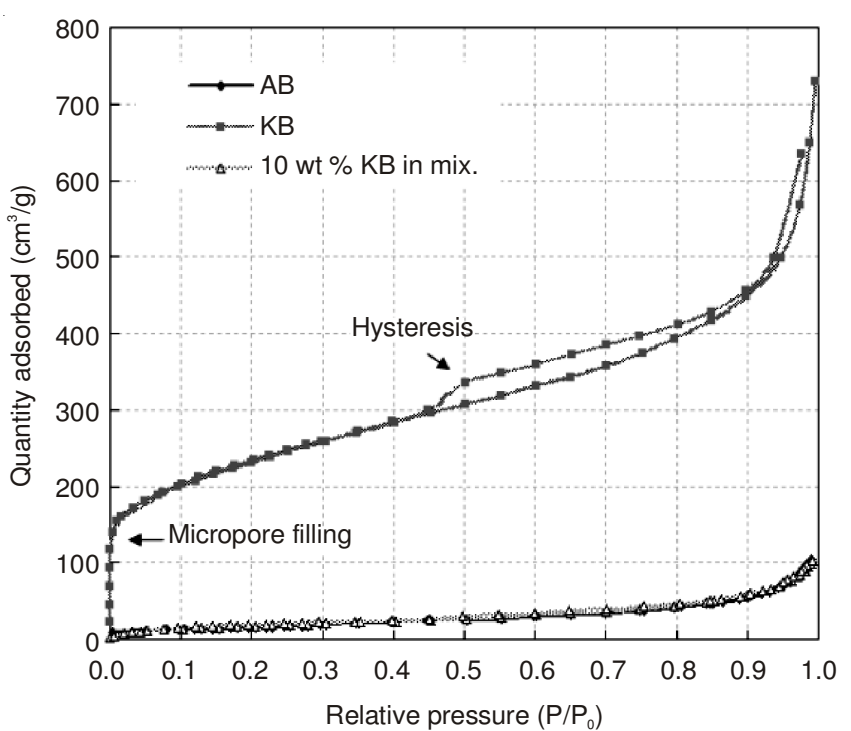

Fig. 3. $\mathrm{N}_{2}$ adsorption isotherms (BET) of carbons: raw carbons $(\mathrm{AB}, \mathrm{KB})$ and dry mixture containing $10 \mathrm{wt} \%$ of $\mathrm{KB}$

quite low relative pressure to actuate a complete filling of the pores which is known as micro-pore filling. In the case of $\mathrm{KB}$, considering quantity adsorbed, number of micro-pores is a little greater than that of meso-pores. Therefore, it can be conclude that KB has various different sizes of pores from micro- to meso-pores although micro size pores are little more dominant. From the isotherm of $\mathrm{AB}$ and mixture of $\mathrm{AB}$ and $\mathrm{KB}$, there is no significant evidence on the existence of microas well as meso-pores throughout the whole range of relative pressure. Results on the $\mathrm{AB}$ and mixture obtained from the isotherm are somewhat similar to that obtained from SEM image which is described above. All of these BET results are summarized in Table-1 including the results obtained from mercury porosimetric measurements. Comparing to $\mathrm{AB}, \mathrm{KB}$ shows $c a$. 15 times greater in surface area and 2.5 times greater in micro-pore volume ratio defined as the volume ratio between micro-pore and total pore. Therefore, addition of $\mathrm{KB}$ into $\mathrm{AB}$ (mixture) brings about an increase in micro-pore volume ratio and surface area as shown in Table-1. Surface area obtained from both BET and mercury pososimetry are well matched in case of $\mathrm{AB}$, which means that $\mathrm{AB}$ has mainly macro-pores with a very small number of micro-pores as confirmed by SEM image. In case of $\mathrm{KB}$, there is big deviation in surface area between two techniques due to the significant contribution of micro-pore distribution. Therefore, in this study, we used BET data for the analysis of the pore distribution effects of the cathode samples on high-rate discharge capacity and cell power.

\begin{tabular}{|c|c|c|c|c|c|c|}
\hline \multicolumn{7}{|c|}{$\begin{array}{l}\text { TABLE-1 } \\
\text { SURFACE AND PORE CHARACTERISTICS OF CARBON RAW MATERIALS AND MIXTURE } \\
\text { OBTAINED FROM BET AND MERCURY POROSIMETRIC MEASUREMENTS }\end{array}$} \\
\hline & \multicolumn{4}{|c|}{$\mathrm{N}_{2}$ adsorption (BET) } & \multicolumn{2}{|c|}{ Mercury porosimetry } \\
\hline & \multirow{2}{*}{$\begin{array}{c}\text { Surface area } \\
\left(\mathrm{m}^{2} / \mathrm{g}\right)\end{array}$} & \multirow{2}{*}{$\begin{array}{c}\text { Total pore } \\
\text { volume }\left(\mathrm{cm}^{3} / \mathrm{g}\right) \\
\end{array}$} & \multicolumn{2}{|c|}{ Pore volume ratio $(\%)$} & \multirow{2}{*}{ Pore area $\left(\mathrm{m}^{2} / \mathrm{g}\right)$} & \multirow{2}{*}{$\begin{array}{l}\text { Pore volume } \\
\left(\mathrm{cm}^{3} / \mathrm{g}\right)\end{array}$} \\
\hline & & & Micro & Meso + macro & & \\
\hline \multicolumn{7}{|l|}{ Raw materials } \\
\hline $\mathrm{AB}$ & 55 & 0.15 & 12.2 & 87.8 & 50 & 1.54 \\
\hline $\mathrm{KB}$ & 808 & 1.02 & 30.1 & 69.9 & 160 & 2.67 \\
\hline \multicolumn{7}{|l|}{ Mixture } \\
\hline $10 \mathrm{wt} \% \mathrm{~KB}$ & 65 & 0.15 & 13.8 & 86.2 & 58 & 1.19 \\
\hline
\end{tabular}


For the investigation of the high-rate discharge characteristics, various carbon cathode samples were prepared by controlling density or KB content in the mixture. Fig. 4 shows $\mathrm{N}_{2}$ adsorption isotherm of carbon electrodes containing 10 weights percent of $\mathrm{KB}$ with various densities; 0.25, 0.27 and $0.30 \mathrm{~g} / \mathrm{cm}^{3}$. No significant difference in adsorption isotherm is noticed from the carbon electrodes having different densities.

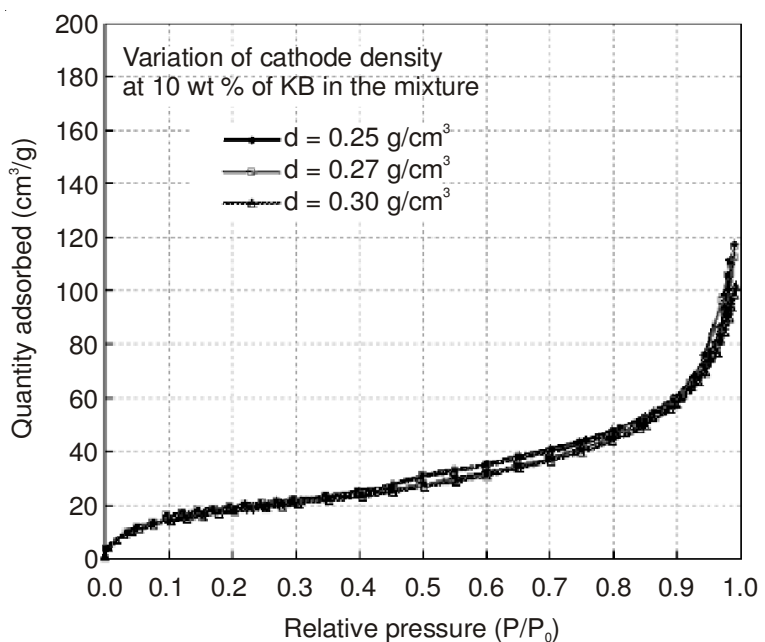

Fig. 4. $\quad \mathrm{N}_{2}$ adsorption isotherms (BET) of carbon cathode containing $10 \mathrm{wt}$ $\%$ of $\mathrm{KB}$ at the densities of $0.25,0.27$ and $0.30 \mathrm{~g} / \mathrm{cm}^{3}$

Fig. 5 shows the adsorption isotherm of carbon electrodes with the variation of $\mathrm{KB}$ contents from 10 to $20 \mathrm{wt} \%$ at a fixed density of $0.3 \mathrm{~g} / \mathrm{cm}^{3}$. Decrease in quantity of adsorbed is realized throughout the whole range of relative pressure as the contents of $\mathrm{KB}$ in the mixture increase from 10 to $20 \mathrm{wt} \%$. This means filling the wide open pores of $\mathrm{AB}$ with $\mathrm{KB}$ particles becomes more significant as the addition contents increase. Results obtained from BET measurements are summarized in Table-2. Upon the effects of cathode density, slight decreases in surface area, pore volume and volume ratio of meso- and macro-pore are observed as the density increases. Whereas, from the studies of the $\mathrm{KB}$ addition effects in the mixture, increases in surface area and pore volume along with the decreases in meso- and macro-pore ratios are noticed as the amount of KB increase due to the penetration of KB particles into wide open network pores of $\mathrm{AB}$ as also shown from the isotherms in Fig. 5. Therefore, it can be concluded that the mixing of the $\mathrm{KB}$ conductive carbon with $\mathrm{AB}$ leads the reduction of meso- and macro-pore distribution although the improvement of electronic conductivity is expected.

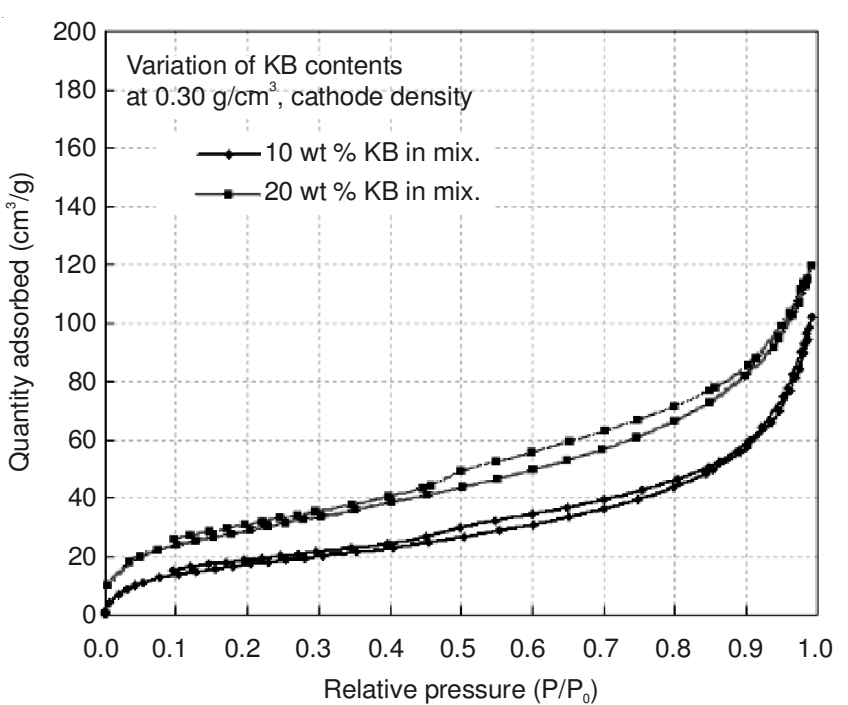

Fig. 5. $\quad \mathrm{N}_{2}$ adsorption isotherms (BET) of carbon cathodes containing 10 and $20 \mathrm{wt} \%$ of $\mathrm{KB}$ at the density of $0.30 \mathrm{~g} / \mathrm{cm}^{3}$

Discharge results and analysis: Fig. 6 shows the effects of carbon electrode density on the discharge capacity. Discharge curves were obtained from bobbin-type D size cell made with the carbon cathode containing $10 \mathrm{wt} \%$ of KB. The cell was discharged to $2 \mathrm{~V}$ with $250 \mathrm{~mA}$ at room temperature. The discharge rate of $250 \mathrm{~mA}\left(6 \mathrm{~mA} / \mathrm{cm}^{2}\right)$ is 2 times of the maximum continues current of the cell. Densities of the carbon electrode made from carbon mixtures containing $10 \% \mathrm{~KB}$ was in the range of 0.17 to $0.20 \mathrm{~g} / \mathrm{cm}^{3}$. As the density becomes higher, increases in working voltage as well as decreases in capacity of the cell are realized as shown in Fig. 6. When the electrode density is increased from 0.17 to $0.20 \mathrm{~g} / \mathrm{cm}^{3}, 24 \%$ of capacity decrease (from 10.25 Ah at $0.17 \mathrm{~g} / \mathrm{cm}^{3}$ to $8.25 \mathrm{Ah}$ at $0.20 \mathrm{~g}$ / $\mathrm{cm}^{3}$ ) is obtained. From the cell made with the electrode density of $0.20 \mathrm{~g} / \mathrm{cm}^{3}$, capacity of 8.25 Ah measured with the current load of $250 \mathrm{~mA}$ is only $43 \%$ of the typical nominal capacity of bobbin D-size cell which is 19 Ah measured with the current load of $4 \mathrm{~mA}^{8}$. In Li/SOCl 2 cell, carbon electrode provides the reaction site and the passivation with reaction products is taking place as the electrochemical reduction of thionyl chloride $\left(\mathrm{SOCl}_{2}\right)$ proceeds during the discharge of the cell. After a certain degree of discharge, the failure of electrodes will be resulted in due to the completion of the pore-filling with insoluble reaction products which are $\mathrm{LiCl}$, mainly ${ }^{9}$. Especially at the high-rate discharge operation, electrode failure can be brought about even before the pore-filling is completed, which is known as the cathode freeze-over phenomena. Fig. 7(a-c) show the

TABLE-2

BET CHARACTERISTICS OF THE CARBON CATHODE HAVING DIFFERENT DENSITIES OR MIXING RATIO

\begin{tabular}{|c|c|c|c|c|}
\hline & \multicolumn{4}{|c|}{$\mathrm{N}_{2}$ adsorption } \\
\hline & \multirow{2}{*}{ Surface area $\left(\mathrm{m}^{2} / \mathrm{g}\right)$} & \multirow{2}{*}{ Total pore volume $\left(\mathrm{cm}^{3} / \mathrm{g}\right)$} & \multicolumn{2}{|c|}{ Pore volume ratio (\%) } \\
\hline & & & Micro & Meso + macro \\
\hline \multicolumn{5}{|c|}{ Density $\left(\mathrm{g} / \mathrm{cm}^{3}\right)$ of electrode made with the mixture containing $10 \mathrm{wt} \% \mathrm{~KB}$} \\
\hline 0.25 & 67 & 0.18 & 12.4 & 87.6 \\
\hline 0.27 & 67 & 0.17 & 12.8 & 87.2 \\
\hline 0.30 & 65 & 0.15 & 13.5 & 86.5 \\
\hline \multicolumn{5}{|c|}{ Mix. ratio of electrode made with the mixture at the density of $0.30 \mathrm{~g} / \mathrm{cm}^{3}$} \\
\hline $10 \mathrm{wt} \% \mathrm{~KB}$ & 65 & 0.15 & 13.5 & 86.5 \\
\hline $20 \mathrm{wt} \% \mathrm{~KB}$ & 106 & 0.18 & 20.1 & 79.9 \\
\hline
\end{tabular}




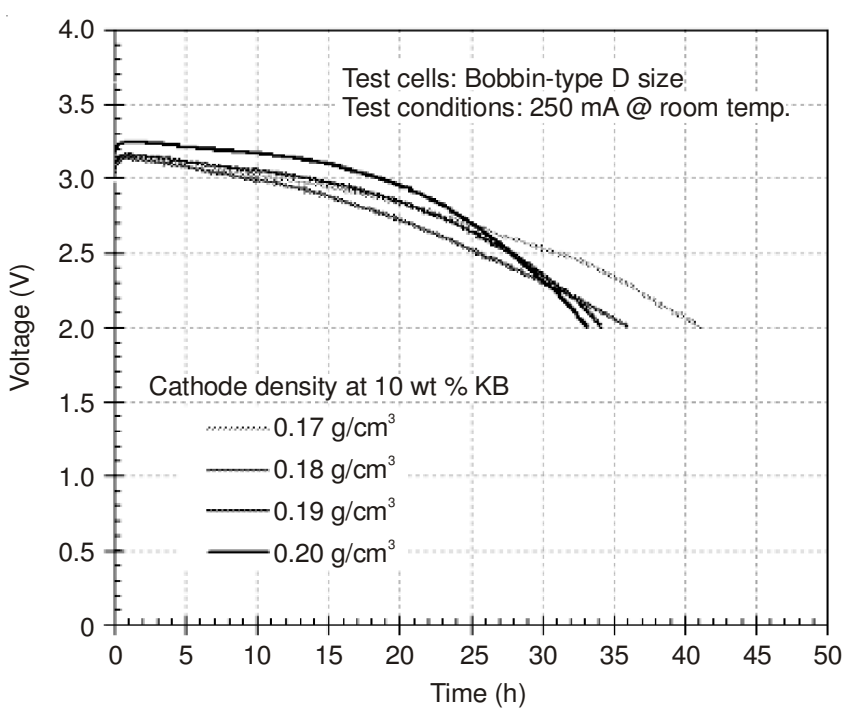

Fig. 6. Discharge curves of bobbin-type D size cell with carbon cathode containing $10 \mathrm{wt} \%$ of $\mathrm{KB}$ at the densities of $0.17,0.18,0.19$ and $0.20 \mathrm{~g} / \mathrm{cm}^{3}$

general optic microscopic images of carbon surfaces generated from high-rate discharge studies at the depth of discharge (DOD) of 0, 50 and $100 \%$, respectively. Passivation of carbon surface by the $\mathrm{LiCl}$ (shown as white particles on the optical images) is significant when the discharge is completed [Fig. 7(c)], while the passivation is not that significant even when the depth of discharge becomes $50 \%$ [Fig. 7(b)]. Upon the effects of electrode density on the capacity of the cell, variations in capacity can be correlated with the changes in pore distribution of the carbon electrode. As described above, pore volume in the range of meso- to macro-pore increases while that of micro-pore decreases as the density of the electrode becomes lower. Deposition of $\mathrm{LiCl}$ is taking place at the inside of large pores first, then progressively extended to smaller pores ${ }^{9}$. Therefore, the increments of large pores in carbon electrode will bring about the increments of discharge capacity. The extent of capacity increment will be more significant when the rate of discharge is higher. Similarly, improvements of high rate discharge performance by the utilization of cathode pore former were confirmed by Klinedinst ${ }^{10}$. By the utilization of cathode pore former such as $\mathrm{NH}_{4} \mathrm{HCO}_{3}$ or $\left(\mathrm{NH}_{4}\right)_{2} \mathrm{CO}_{3}$, he could increase the number of the large pores having about $200 \mu \mathrm{m}$ in diameter. As a result of the enrichments of large pores, 30 and $45 \%$ improvements in cathode utilization efficiency at the high-rate discharge $\left(140 \mathrm{~mA} / \mathrm{cm}^{2}\right)$ were confirmed from $\left(\mathrm{NH}_{4}\right)_{2} \mathrm{CO}_{3}$ and $\mathrm{NH}_{4} \mathrm{HCO}_{3}$, respectively.

Fig. 8 shows the effects of KB contents in carbon mixture having density fixed at $0.20 \mathrm{~g} / \mathrm{cm}^{3}$ on the high-rate discharge performance at $250 \mathrm{~mA}$ current load. Significant capacity loss along with the modest increase in working voltage is observed as the content of $\mathrm{KB}$ in the carbon mixture increases from 10 to $50 \mathrm{wt} \%$. Increment in working voltage, although it is not that significant, could be explained by the higher electronic conductivity and larger surface area of the KB added. Capacities of 8.25, 6 and 3.75 Ah are obtained when the contents of KB are 10,30 and $50 \%$, respectively. The loss of capacity is $55 \%$ as the contents of $\mathrm{KB}$ increase from 10-50\%. Capacity loss, as the KB contents increase, can be explained by the decreases

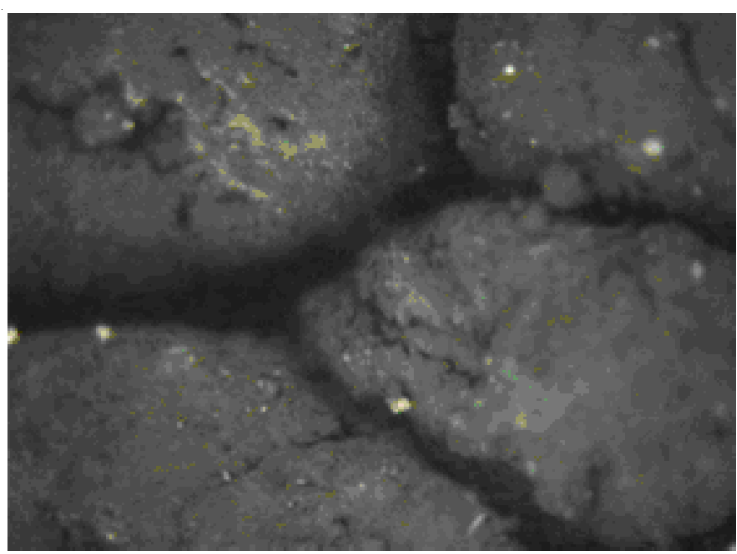

(a)

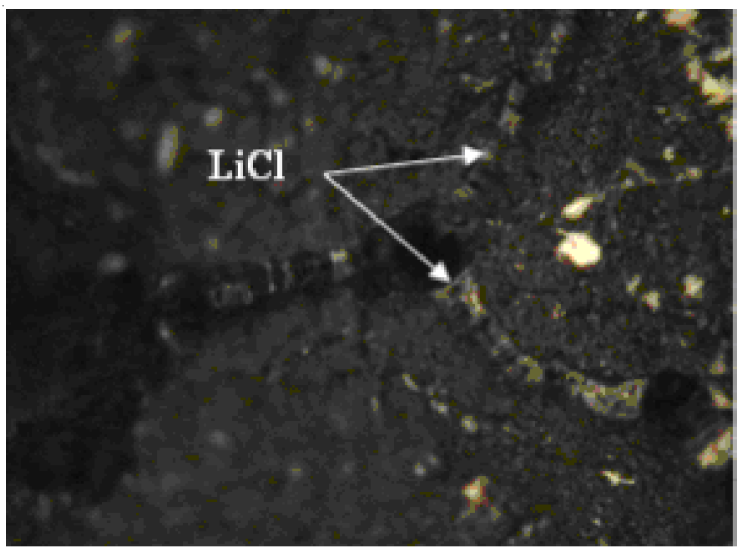

(b)

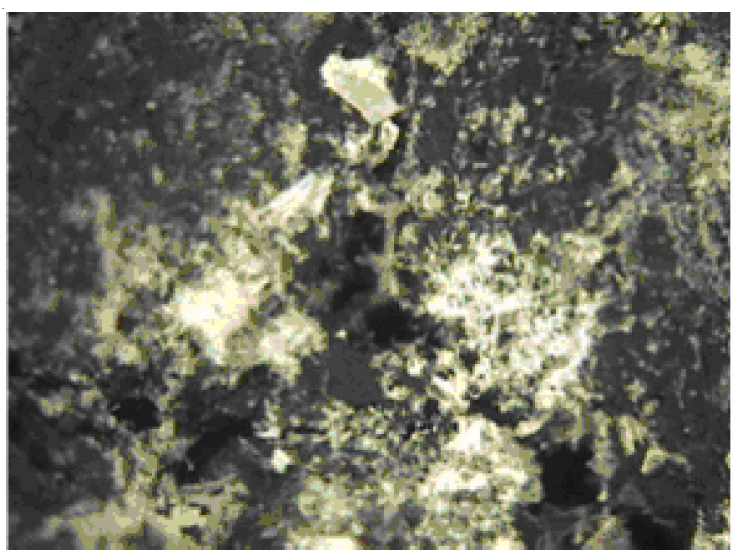

(c)

Fig. 7. Optic microscopic photographs of the surface of carbon cathode magnified at 300 times at the depth of discharge (DoD) of (a) $0 \%$, (b) $50 \%$ and (c) $100 \%$

in the number of meso- to macro-pores in which electrochemical reduction products, $\mathrm{LiCl}$, will be precipitated,. As described above, a possible reason for the decrease in pore size and number of the larger pores is that wide open network pores formed by an $\mathrm{AB}$ aggregate are partially filled with $\mathrm{KB}$ particles as shown in SEM image of mixture in Fig. 1(c).

Fig. 9 shows the comparison plot of capacity (Ah) and cell power $(\mathrm{W}) v s$. cathode density and content of KB. As shown in the figure, decrease in capacity is observed as either of cathode density or KB content go down. And the slope of the decrease is more significant with the KB contents. Considering 


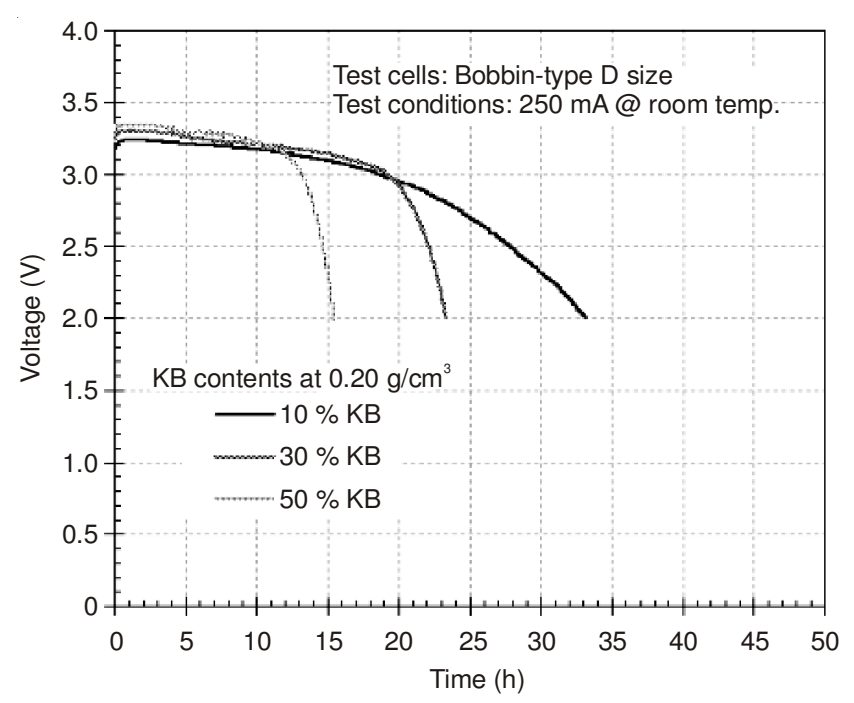

Fig. 8. Discharge curves of bobbin-type D size cell with carbon cathodes containing 10,30 and $50 \mathrm{wt} \%$ of $\mathrm{KB}$ at the density of $0.20 \mathrm{~g} / \mathrm{cm}^{3}$

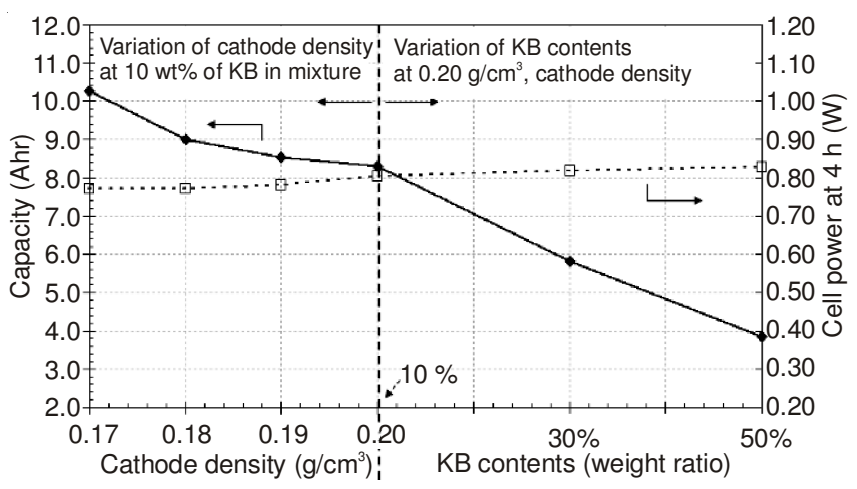

Fig. 9. Comparison plots of high-rate capacity ( ) and cell power ( $\square$ ) vs. cathode density (with the cathode containing $10 \mathrm{wt} \%$ of $\mathrm{KB}$ ) and $\mathrm{KB}$ contents (with the cathode at the density of $0.20 \mathrm{~g} / \mathrm{cm}^{3}$ )

the pore distribution data represented at Table-2, trend of capacity loss shown in this plot can be correlated with the changes in pore volume, especially volume of the meso- and macro-pores. It is also concluded that the effective pore size of the carbon cathode for high-rate discharge is the pores in meso- to macro-pore range rather than micro-pores.

From the plot of cell power (represented with \%) and its value at the right-hand side of Y-axis in Fig. 9, slight increases in cell power is noticed as either cathode density or KB contents go up. These results could be related with pore distribution of the carbon electrode also, but rising tendency of cell power as a function of cathode density and KB contents seems adverse to that of capacity. Therefore, the method to increase the highrate capacity leads to the reduction of cell power.

\section{Conclusion}

Electrochemical characteristics of the $\mathrm{Li} / \mathrm{SOCl}_{2}$ cells are known to be affected by the pore size distributions of carbon cathode. In this study, we modified the pore distribution of carbon electrodes by the variation of either cathode density or $\mathrm{KB}$ contents in the mixture and then analyzed the effects of pore characteristics on the high-rate capacity and the cell power. From the correlation studies of high-rate discharge characteristics with SEM images, mercury porosimetry and BET results, it was concluded that the more effective pores for the improvement of the high-rate capacity seemed to be relatively larger pores (pores in meso to macro range) rather than micropores. Upon the meso to macro range pores, $A B$ has more significant number of them than $\mathrm{KB}$ does. It was also realized that the changes in the number of larger pores on $\mathrm{AB}$ were not significant with the variation of cathode density, while it was more significant with the variation of the KB contents. Comparing to the cathode density modification method, KB contents variation method causes more serious reduction in high-rate capacity. Therefore, the more effective way to improve highrate characteristics of $\mathrm{Li} / \mathrm{SOCl}_{2}$ cell is the density adjustment of the cathode having relatively larger pores, such as AB based cathode.

\section{ACKNOWLEDGEMENTS}

This work was supported by Ministry of Knowledge Economy as part of the "World Class 300 Project" and was performed by the quality improvement activities of Defense Agency for Technology and Quality.

\section{REFERENCES}

1. D. Linden, Lithium Cells: Handbook of Batteries and Fuel Cells, McGraw Hill Book Co., New York, pp. 11-1-11-90 (1984).

2. A.N. Dey and P. Bro, In ed.: D.H. Collins, Power Sources: Primary Li/ $\mathrm{SOCl}_{2}$ Cells III, Academic Press, London, Vol. 6, p. 493 (1977).

3. A.N. Dey and R.W. Holmes, J. Electrochem. Soc., 127, 775 (1980).

4. J.A. Christopulos and S. Gilman, In Proceedings of the 10 Intersociety Energy Conversion Engineering Conferences, IEEE publisher, DE, p. 437 (1975).

5. D. Carmier, C. Vix-Guterl and J. Lahaye, J. Power Sources, 103, 237 (2002).

6. D. Carmier, C. Vix-Guterl and J. Lahaye, Carbon, 39, 2181 (2001).

7. D. Carmier, C. Vix-Guterl and J. Lahaye, Carbon, 39, 2187 (2001).

8. http://www.vitzrocell.com/product/e_pr_01.php.

9. V.S. Bagotzky, V.E. Kazarinov, Y.M. Vol'fkovich, L.S. Kanevsky and L.A. Berketayeva, J. Power Sources, 26, 427 (1989).

10. K.A. Klinedinst, J. Electrochem. Soc., 132, 2044 (1985) 